\title{
Sperm ultrastructure in two species of the polychaete genus Harmothoe (Polynoidae)
}

\author{
M. G. Bentley* \& Katrin Serries** \\ Gatty Marine Laboratory, Department of Biology and Pre-clinical Medicine, University of \\ St Andrews; Fife, KY16 8LB, Scotland, U.K.
}

\begin{abstract}
The structure of spermatozoa is described for two species of polynoid polychaete, Harmothoe imbricata and Harmothoe impar, from material fixed and examined by both scanning and transmission electron microscopy. The two species undergo spermiogenesis within discrete testes. The testis of $H$. imbricata is shown to have a layer of epithelial cells which possess an outer cuticular layer and a microvillous inner surface. Spermatocytes of both species are spherical but there are marked differences in the shape and size of the spermatozoa of the two species. $H$. impar has a classical primitive spermatozoon with a rounded head ( $2 \mu \mathrm{m}$ long) and a button-shaped acrosome. Fully differentiated spermatozoa of $H$. imbricata are modified from the primitive form by having a long head ( $10 \mu \mathrm{m}$ length) with a pointed acrosome about $6 \mu \mathrm{m}$ in length. Spermatozoa of $H$. imbricata have a ring of up to fourteen mitochondria around a centrally inserted flagellum at the posterior whereas $H$. impar has a ring of four or five spherical mitochondria. Spermiogenesis is well synchronised in $H$. imbricata but all developmental stages can be found simultaneously in the testis of $H$. impar. The differences in sperm structure of the two species may be related to differences in breeding biology which are hitherto unknown.
\end{abstract}

\section{INTRODUCTION}

The polychaetes Harmothoe imbricata and Harmothoe impar are two species of scale worm which inhabit the intertidal zone of rocky shores. They are found beneath stones which afford both cover from wave action and protection from predators but where there is no appreciable silt deposition (Daly, 1972). They are typically solitary species and are voracious carnivores which may show cannibalistic tendencies. The reproductive biology of $H$. imbricata has been described by Daly $(1972,1974)$ and later by Garwood $(1980$, 1981) and Garwood \& Olive (1982). Unlike the majority of polychaetes which spawn by releasing large numbers of gametes into the water column these polynoid species show brooding behaviour in which the females carry the fertilised eggs beneath the dorsal elytra. Associated with this modified form of reproduction there are also other behavioural modifications, which involve pairing of males and females and suppression of the female aggression towards other members of the same species. Spawning of $H$. imbricata, which has an annual cycle of reproduction, takes place in the spring. Two

\footnotetext{
- Addressee for reprint requests

* Present address: Institut für Biologie I (Zoologie), Albert-Ludwigs-Universität Freiburg; Albertstraße 21 a, D-W-7800 Freiburg, Federal Republic of Germany
} 
batches, or cohorts, of eggs are released: one, for populations in North-East England, usually in March and the second a few weeks later, in late April or May (see Clark, 1988).

The structure of marine invertebrate spermatozoa has been discussed in a number of review articles including those of Franzén $(1956,1975,1987)$ and those of Olive (1983) and Sawada (1984) on spermatozoa of Polychaeta. It has been suggested by a number of authors, and it is now widely accepted, that "primitive sperm" as described by Franzén (1956) (ovoid head, unmodified flagellum) are associated with shedding of gametes into the water column and external fertilisation. "Aberrant" or modified spermatozoa, which may have an elongated head and a coiled or even absent flagellum, are typically associated with a modified mode of reproduction such as the use of spermatophores for sperm transfer or internal fertilisation.

Daly (1974) observed differences in the shape of spermatozoa, at the light microscope level, between those of $H$. imbricata which is noted as "having an elongated nucleus and long conical acrosome" and those of $H$. impar which is of the primitive type with an ovoid head. These observations, coupled with the fact that there is some modification in breeding biology, from the simple form of gamete shedding and external fertilisation, suggested to us that the spermatozoa of these species warranted a more detailed examination.

\section{MATERIALS AND METHODS}

\section{Animals}

Specimens of Harmothoe imbricata and Harmothoe impar were collected from beneath stones at low water of spring tides from two sites: Kinkell Braes, St. Andrews, and Kingsbarns, Fife, during January-April 1991. The animals were kept in seawater at $5{ }^{\circ} \mathrm{C}$ and fixation for electron microscopy was carried out within a few days of collection. Animals were narcotised with $0.07 \%$ MS 222 in seawater before dissection of the gonads. The testes were removed through an incision made in the lateral body wall between the parapodia with the aid of a micropipette. An alternative method was also employed which involved the removal of the testes via an opening to the coelom created by excising a parapodium.

\section{Electron microscopy}

Fixation of testes for scanning electron microscopy was carried out in $3 \%$ glutaraldehyde in $0.1 \mathrm{M}$ Phosphate buffer at $\mathrm{pH} 7.2$ with $0.26 \mathrm{M} \mathrm{NaCl}$ for 60 to $90 \mathrm{~min}$ at $20^{\circ} \mathrm{C}$. Samples for scanning electron microscopy were then rinsed in $0.2 \mathrm{M}$ Phosphate buffer at $\mathrm{pH} 7.2$ for 3 minutes. Dehydration was carried out via an alcohol series (50\% ethanol, $1 \mathrm{~h}$; $70 \%, 15 \mathrm{~min}_{\mathrm{i}} 96 \%, 15 \mathrm{~min} ; 3$ changes each of $15 \mathrm{~min}$ in absolute ethanol). The samples were critical point dried in an EMSCOPE Samdri-780 critical point dryer, mounted on brass stubs, coated with gold to a depth of 10-12 $\mathrm{nm}$ in an EMSCOPE SC sputter coater and examined on a JEOL JSM-35 CF scanning electron microscope.

Samples for transmission electron microscopy were fixed as for scanning electron microscopy, rinsed in $0.1 \mathrm{M}$ Phosphate buffer with $0.26 \mathrm{M}$ sucrose for $10 \mathrm{~min}$ and then post-fixed in $1 \% \mathrm{OsO}_{4}$ and $0.05 \mathrm{M}$ Phosphate buffer (pH 7.2) with $0.13 \mathrm{M} \mathrm{NaCl}$ for 15 minutes. The samples were washed in distilled water, stained with uranyl acetate for $30 \mathrm{~min}$ and rinsed again in distilled water. Dehydration was carried out via an acetone 
series ( $50 \%, 5 \mathrm{~min} ; 70 \%, 5 \mathrm{~min} ; 90 \%, 5 \mathrm{~min} ; 100 \%, 3$ changes each of $5 \mathrm{~min}$ ). Samples were transferred to an Araldite : acetone mixture $(4: 1 \mathrm{v} / \mathrm{v})$ overnight, and then embedded in Araldite. Polymerisation took place for three days at $60^{\circ} \mathrm{C}$. Sections were cut on a $\mathrm{OM}$ U2-ultramicrotome and mounted on plastic coated (colloidon in amyl acetate) 200 mesh copper grids (EMscope).

Prior to examination with the transmission electron microscope, the sections were double stained with lead citrate $(5 \mathrm{~min})$ and uranyl acetate $(5 \mathrm{~min})$ and examined with a PHILIPS 301-transmission electron microscope.

\section{RESULTS}

\section{Harmothoe imbricata}

The early testis of Harmothoe imbricata is a discrete structure which is covered by a layer of epithelial cells. Figure 1 shows a testis of $H$. imbricata in which spherical spermatocytes (of about $7 \mu \mathrm{m}$ diameter) are visible in areas which have been ruptured during preparation for electron microscopy. The testis wall consists of a single layer of cells which have a cuticular outer membrane and a microvillous inner surface (Fig. 2). The nuclei of these cells are irregular, heterogenous structures and the cytoplasm contains numerous vesicular inclusions and a few spherical mitochondria. Figure 3 shows a detail of the microvillous surface and the nucleus of an epithelial cell. Ribosomes can be seen associated with some of the peri-nuclear membranes.

As spermatogenesis proceeds, spermatids can be found. Each spermatid shows polarisation of the cell, elongation and the commencement of development of the flagellum (Figs 4,5 ). The spermatids at this stage are about $8 \mu \mathrm{m}$ in length and about $4 \mu \mathrm{m}$ across. Elongation of the flagellum and development of the acrosome result in spermatozoa which have a head length (including acrosome) of about $10 \mu \mathrm{m}$ and which are shown in Figure 6. Spermatozoa, as they approach completion of development often show a curved head shape with a straight acrosome and there is a pronounced network of fibrils extending anteriorly from the mitochondrial region across the head of the spermatozoon. The head of the fully differentiated spermatozoon is straight, and sperm nucleus and acrosome lie in a straight line (Fig. 7). Longitudinal sections of spermatozoa in the testis at a late stage of development illustrate this (Fig. 8). Figure 9 shows a section through a region of the testis where the spermatozoa have been sectioned transversely. Rings of up to 14 mitochondria can also be seen. All regions of the spermatozoa are visible in this figure. Spermatozoa appear to be in alignment within the testis and, for this reason, sections tend to show cells all lying in the same plane. Figure 10 shows a scanning electron micrograph of a single spermatozoon of $H$. imbricata indicating the ring of mitochondria, the extra-nuclear fibrils and the long tapering acrosome which is about $6 \mu \mathrm{m}$ in length. Longitudinal sections of the mature spermatozoon show that there is a long nucleus and acrosome and the mitochondria form a cup shape into which the nucleus of the spermatozoon sits (Fig. 11). The acrosome has an apical position at the anterior tip of the nucleus but there is no obvious external sign of the transition from nucleus to acrosome (Fig. 10). The peripheral part of the acrosome consists of dense material forming a cortical ring and a less dense core (Fig. 12). The flagellum is inserted centrally at the posterior of the sperm head (Fig. 13). Figure 14 is a section through the 

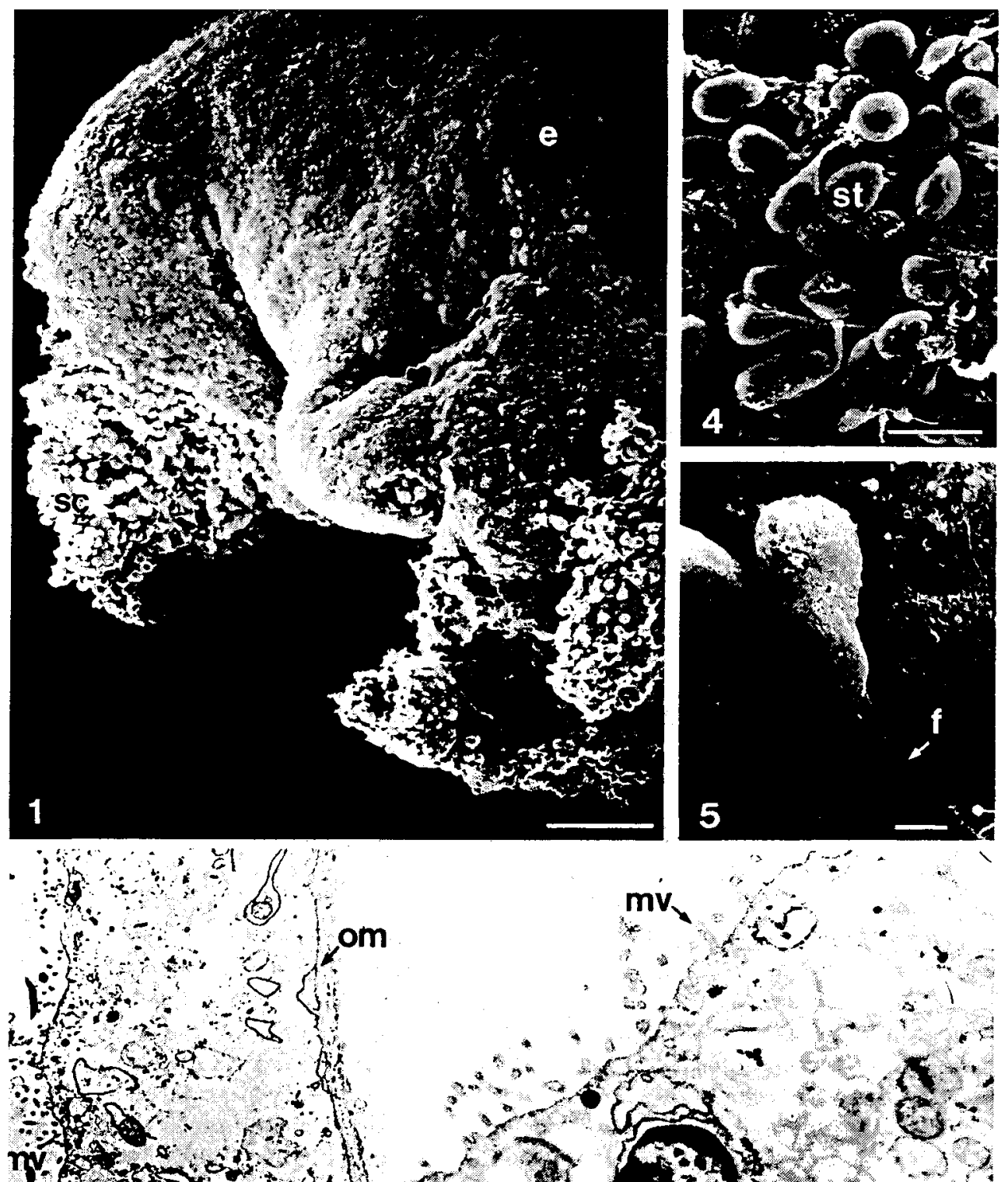

और है।

$\therefore$ to $k$ om

$m v_{y}$

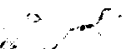


outer region of the testis and shows the relationship between the epithelial cells of the testis wall and the fully differentiated sperm cells. It is clear that the epithelial covering persists in the mature testis and its intra-cellular appearance is also the same as observed in the earlier testis.

Figures 15 and 16 illustrate details of transverse sections through mature spermatozoa. The flagella show the typical $9+2$ pattern of the microtubules, the mid-region of the acrosome can be distinguished as having a dense cortex and a less dense inner region. The posterior part of the acrosome, however, shows finger-like processes extending posteriorly around the nucleus. The nucleus of the spermatozoon is about $1 \mu \mathrm{m}$ in diameter across the mid-region and the interior of the nucleus shows a distinct granular or crystalline structure.

\section{Harmothoe impar}

Figure 17 shows fully differentiated spermatozoa of Harmothoe impar which, in contrast to the spermatozoa of Harmothoe imbricata, are of the primitive type. The head is ovoid and about $2 \mu \mathrm{m}$ in length with a very pronounced "button-shaped" acrosome at the anterior. The number of mitochondria varies between four and five and they have a simple spherical shape. The flagella are long and unmodified. A section through the testis of $H$. impar (Fig. 18) reveals the presence of a number of different developmental cell stages indicating asynchronous development of spermatozoa in this species. This is also clearly apparent in scanning electron micrographs (Fig. 19). Spherical spermatocytes, spermatids with short curled flagella and fully differentiated spermatozoa are present simultaneously. Longitudinal sections show the pronounced acrosomal button and the ellipsoid shape of the nucleus. The nucleus of the fully differentiated spermatozoon has a homogenous appearance and a diameter of about $1 \mu \mathrm{m}$. The middle piece is represented by a ring of spherical mitochondria with the flagellum inserted centrally. Each spermatozoon appears to be surrounded by an expanded membrane (Figs 20, 21). A section through the middle piece region shows four spherical mitochondria surrounding the centriolar complex (Fig. 22) and sections of the tail region once again show a typical $9+2$ pattern of the microtubules (Fig. 23). In Figure 24, two axonemes are surrounded by a single membrane. Whilst the nucleus of the spermatozoon is characterized by a homogenous appearance, earlier sperm cell stages show the process of chromatin condensation (Figs 25-27). There is a corresponding decrease in diameter of the cell

Fig. 1. Early testis of Harmothoe imbricata. The testis is covered with a layer of epithelial cells. Spermatocytes are visible at areas where the outer wall of the testis has become disrupted. Scale bar $=50 \mu \mathrm{m}$ (e = epithelial layer, $\mathrm{sc}=$ spermatocytes $)$

Fig. 2. Section through the testicular wall of Harmothoe imbricata showing a cuticular outer membrane and nucleus of the epithelial cell. Microvilli are visible on the inner surface. Scale bar = $2 \mu \mathrm{m}$ (om = outer membrane, $\mathrm{mv}=$ microvilli, $\mathrm{n}=$ nucleus)

Fig. 3. Harmothoe imbricata. Detail of the nucleus and the microvilli surface of the epithelial cell. Scale bar $=1 \mu \mathrm{m}$ ( $\mathrm{n}=$ nucleus, $\mathrm{mv}=$ microvilli)

Fig. 4. Spermatids of Harmothoe imbricata showing elongation and development of the flagellum. Scale bar $=10 \mu \mathrm{m}$ (st $=$ spermatids $)$

Fig. 5. Elongating spermatids of Harmothoe imbricata illustrating the bipolar shape and the flagellum. Scale bar $=2 \mu \mathrm{m}$ ( $\mathrm{f}=$ flagellum) 


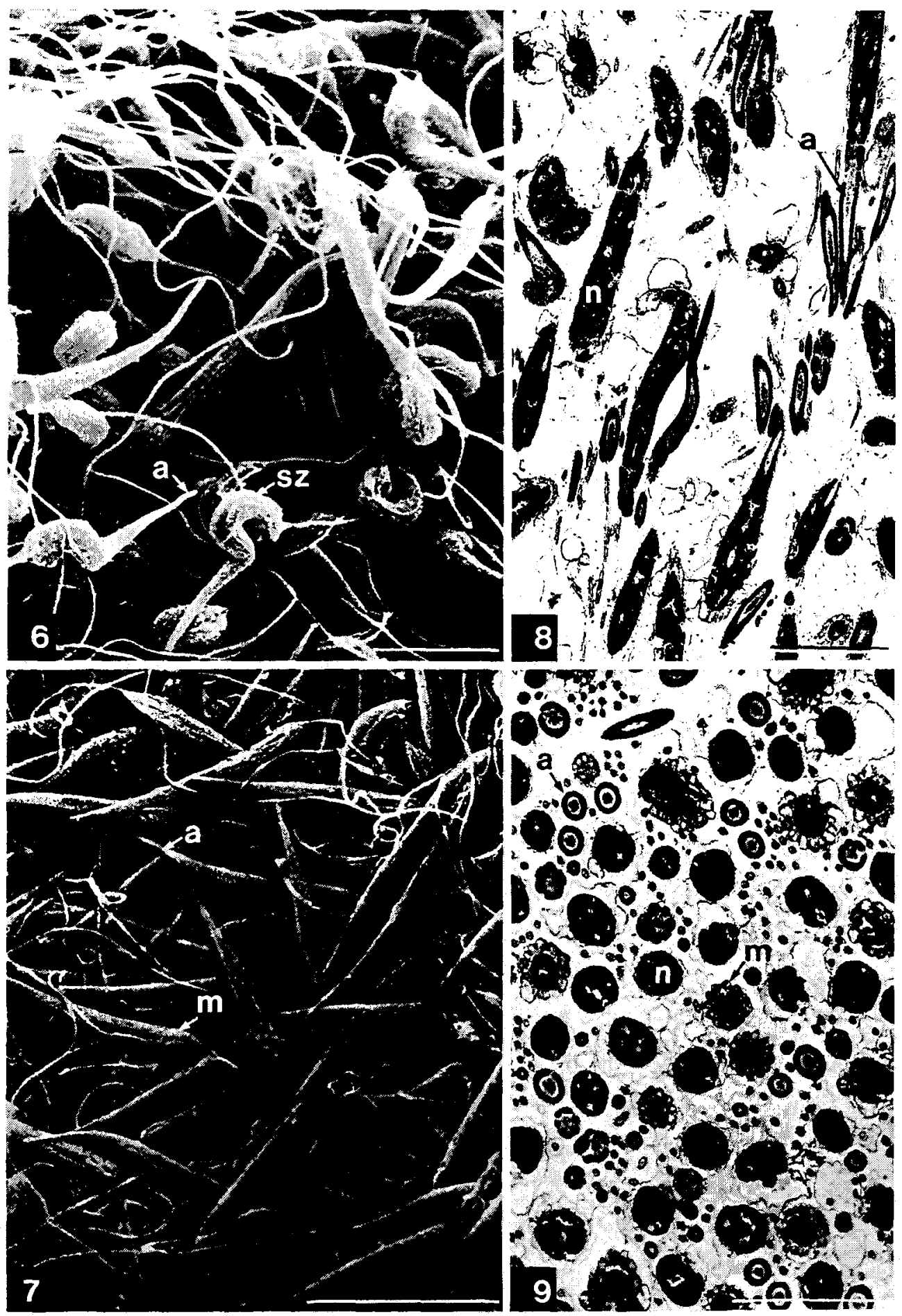


during nuclear condensation with nuclear diameter decreasing from $4 \mu \mathrm{m}$ to the final diameter of about $1 \mu \mathrm{m}$.

\section{DISCUSSION}

Ultrastructural observations presented here on the two species of Harmothoe confirm the light microscopical observations of Daly $(1972,1974)$. Harmothoe imbricata has an elongated nucleus and pointed acrosome whereas Harmothoe impar has a classical rounded head of a primitive type of spermatozoon. Daly's observations on the size of the sperm head of $H$. imbricata appear, however, to overestimate its size. The present study indicates that the length of the head in this species is around $10 \mu \mathrm{m}$. Interestingly, observations of two axonemes within a single membrane have also been described in other polychaete species including Arenicola marina (Pacey \& Bentley, in prep.) and whilst these could be interpreted as a modification of the distal region of the flagellum in which the axoneme becomes folded back on itself to create a paddle shaped end to the flagellum (Bentley \& Pacey, 1989) it is perhaps more likely that they are in fact artifactual.

The spermatozoa of $H$. impar are similar in their morphology to many other polychaete spermatozoa which have been described such as Arenicola brasiliensis (Sawada, 1975), A. marina (Bentley \& Pacey, 1989; Pacey \& Bentley, in prep.) and Nereis diversicolor (Bertout, 1976) (see also Sawada, 1984 for review). These polychaetes are characterised by external fertilisation. Modified spermatozoa have been described in a number of polychaete species, including Polydora spp. and Streblospio benedicti (Rice, 1981) and species of the family Capitellidae (Eckelbarger \& Grassle, 1987). Smaller polychaetes, particularly interstitial species, often possess this kind of spermatozoon which may be associated with a specialised mode of reproduction such as the transfer of spermatophores between individuals of Hesionides arenarid (Westheide, 1984) and nonmotile, modified spermatozoa of Ophryotrocha species (Pfannenstiel \& Grünig, 1990) which reproduce by means of pseudocopulation.

Dimorphism in sperm structure for two species of the same polychaete genus, as is described here for $H$. imbricata and $H$. impar, has also been described for two species of Platynereis: $P$. dumerilii has a primitive type of spermatozoon with a spherical head whereas $P$. massiliensis has an elongated head (Lücht \& Pfannenstiel, 1989). In these two species of Platynereis the observed differences in sperm morphology are related to differences in breeding biology, with $P$. dumerilii showing gamete release followed by external fertilisation and $P$. massiliensis undergoing pairing and pseudocopulation (Pfannenstiel et al., 1987).

Fig. 6. Spermatozoa of Harmothoe imbricata showing the pointed acrosome which is orientated at a slight angle to the nucleus of each cell. Scale bar $=5 \mu \mathrm{m}$ (sz $=$ spermatozoa, $\mathrm{a}=$ acrosome)

Fig. 7. Fully differentiated spermatozoa of Harmothoe imbricata. Acrosome and nucleus are in a straight line. The posterior part of the nucleus is surrounded by mitochondria. Scale bar $=10 \mu \mathrm{m}$ ( $a=$ acrosome, $m=$ mitochondria)

Fig. 8. Longitudinal section through the testis of Harmothoe imbricata. Scale bar $=4 \mu \mathrm{m}(\mathrm{a}=$ acrosome, $\mathrm{n}=$ nucleus)

Fig. 9. Transverse section through the testis of Harmothoe imbricata. Scale bar $=4 \mu \mathrm{m}(\mathrm{m}=$ mitochondria, $\mathrm{a}=$ acrosome, $\mathrm{n}=$ nucleus) 

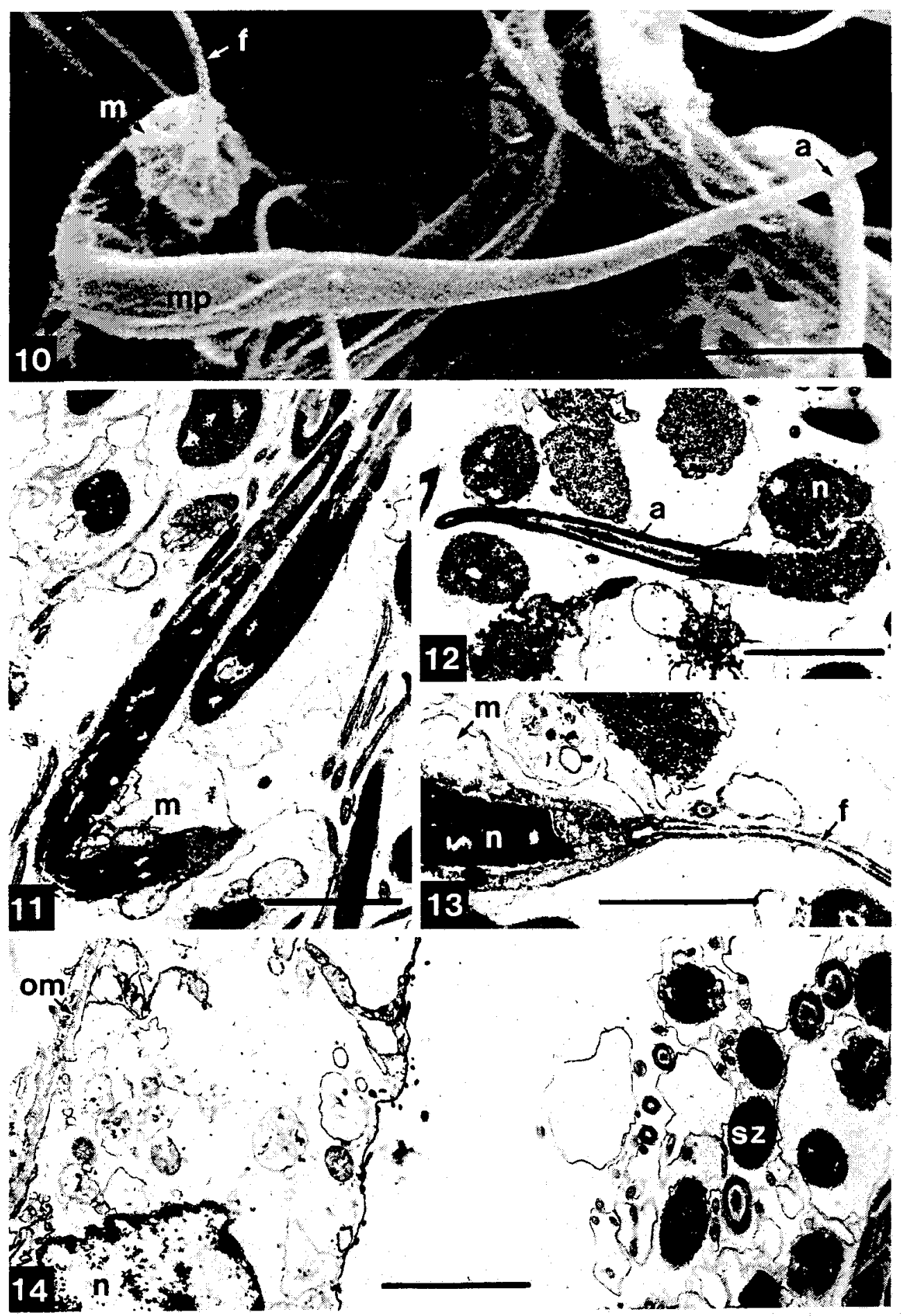


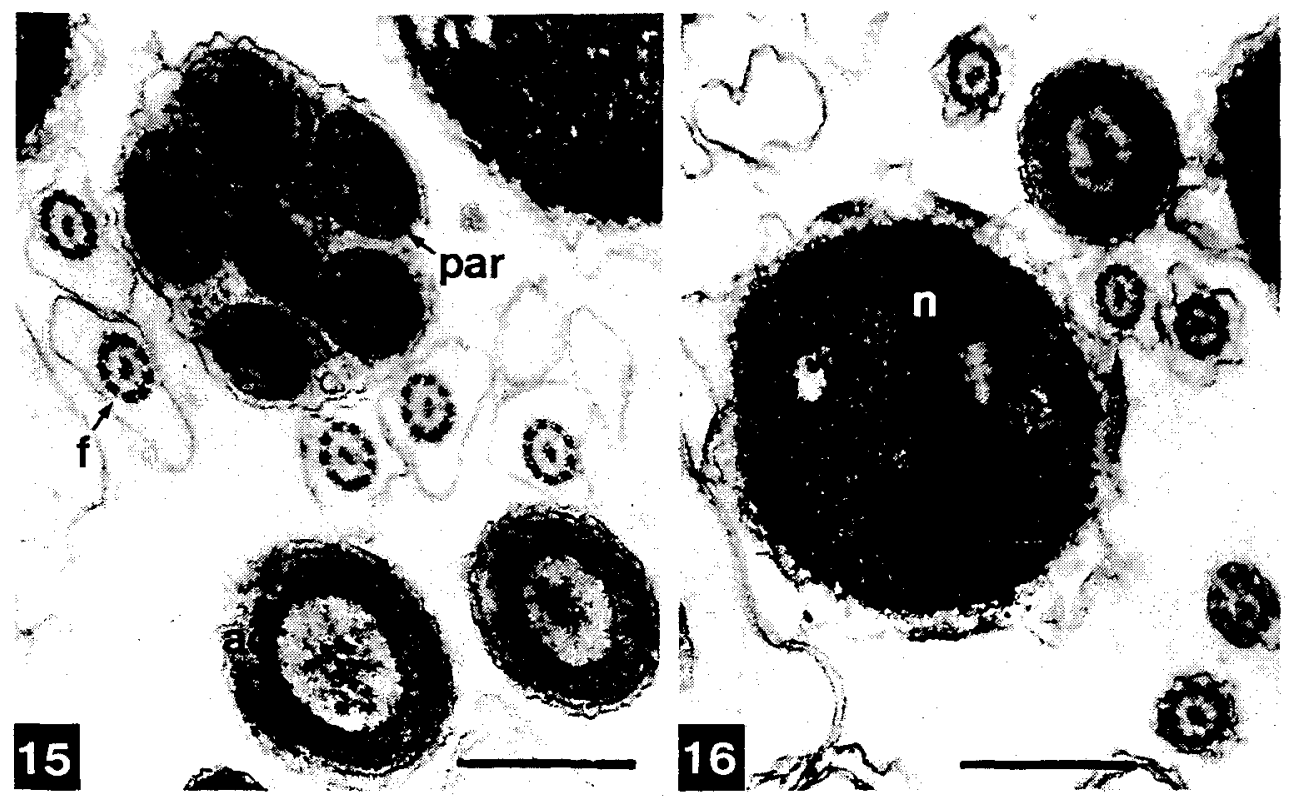

Fig. 15. Transverse section through the testis of Harmothoe imbricata. Sections through the flagellum show the typical $9+2$ pattern, through the acrosomal region showing a dense acrosomal cortex and a lesser dense inner region and through the posterior acrosomal region showing finger-like processes. Scale bar $=0.5 \mu \mathrm{m}$ (ac $=$ acrosomal cortex, $\mathrm{f}=$ flagellum, par $=$ posterior acrosomal region)

Fig. 16. Harmothoe imbricata. Transverse-sectioned nucleus with a dense granular structure. Scale bar $=0.5 \mu \mathrm{m}(\mathrm{n}=$ nucleus $)$

Fig. 10. Single spermatozoon of Harmothoe imbricata showing the elongated pointed acrosome, the mid-piece and the ring of mitochondria. A single flagellum is inserted posteriorly. Scale bar $=2 \mu \mathrm{m}$ ( $\mathrm{a}=$ acrosome, $\mathrm{mp}=$ mid-piece, $\mathrm{m}=$ mitochondria, $\mathrm{f}=$ flagellum)

Fig. 11. Longitudinal section through a mature spermatozoon of Harmothoe imbricata showing the acrosome, the nucleus and the mitochondria. Scale bar $=3 \mu \mathrm{m}(\mathrm{a}=$ acrosome, $\mathrm{n}=$ nucleus, $\mathrm{m}=$ mitochondria)

Fig. 12. Longitudinal section through the acrosome and the anterior part of the nucleus of a mature spermatozoon of Harmothoe imbricata. The acrosomal region can be distinguished by the presence of a dense cortex and a lesser dense inner region. Scale bar $=3 \mu \mathrm{m}$ ( $\mathrm{a}=$ acrosome, $\mathrm{n}=$ nucleus)

Fig. 13. Longitudinal section through the posterior region of the spermatozoon of Harmothoe imbricata showing the nucleus, the mitochondria and the insertion of the flagellum. Scale bar $=2 \mu \mathrm{m}$ ( $\mathrm{n}=$ nucleus, $\mathrm{m}=$ mitochondria, $\mathrm{f}=$ flagellum)

Fig. 14. Section through the outer region of the testis of Harmothoe imbricata. The epithelial covering is closely related to the mature sperm cells. Scale bar $=3 \mu \mathrm{m}$ ( $\mathrm{n}=$ nucleus, om $=$ outer membrane, $s z=$ spermatozoa) 

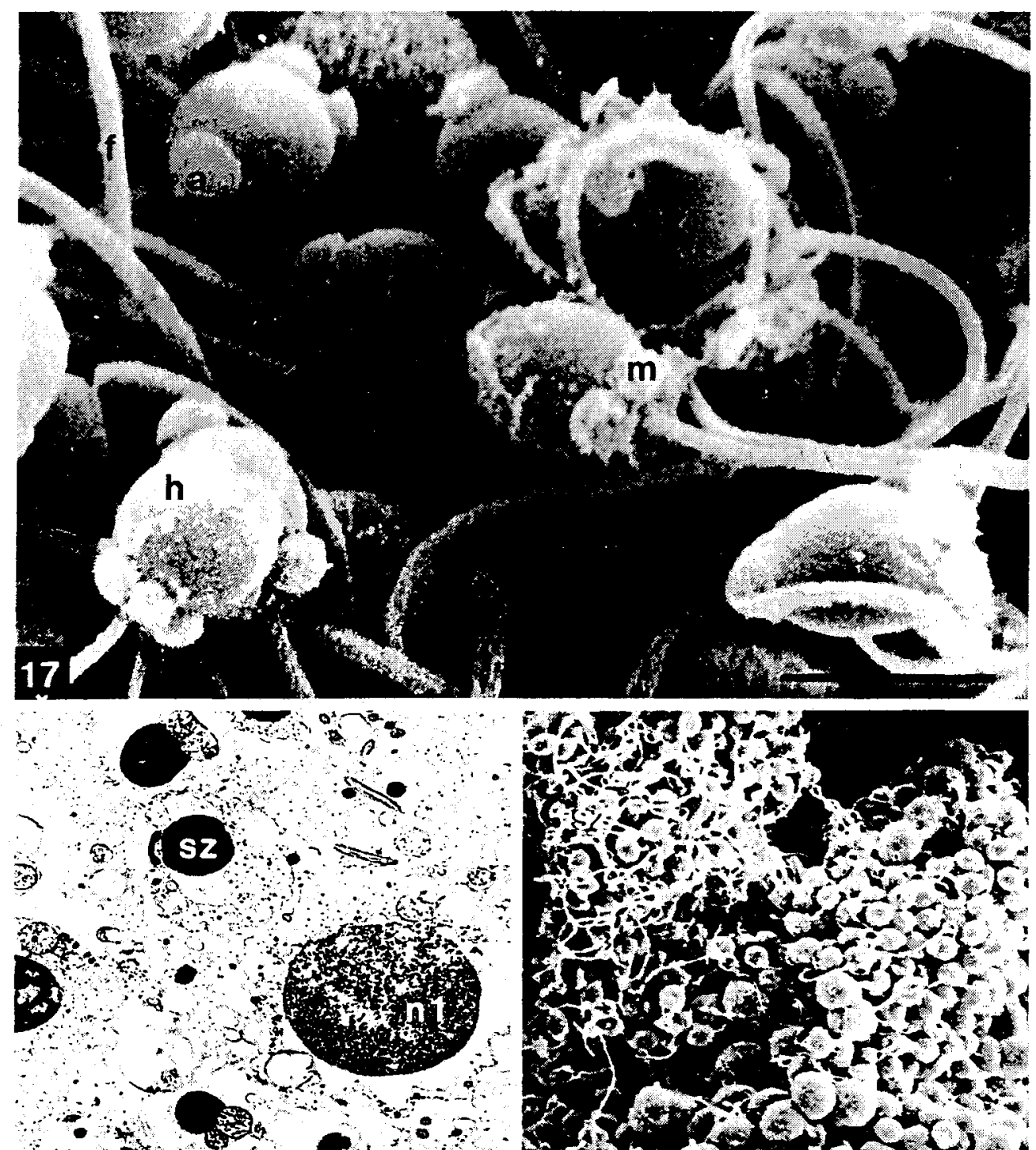

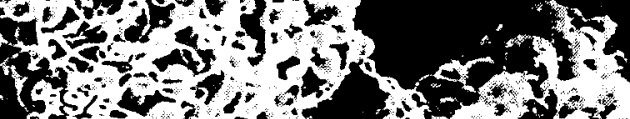

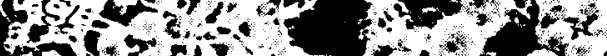
H.5.

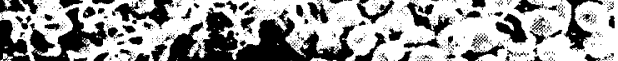

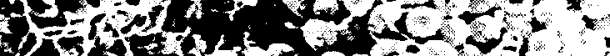

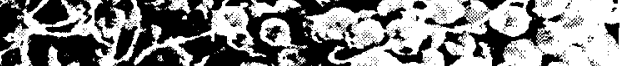

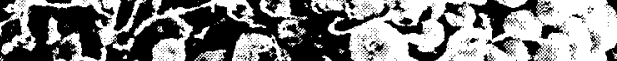

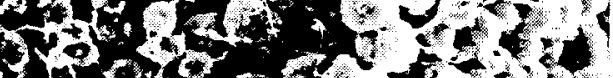

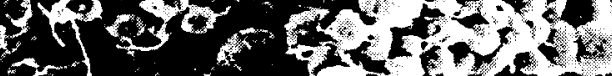

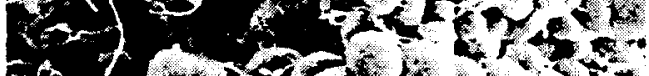

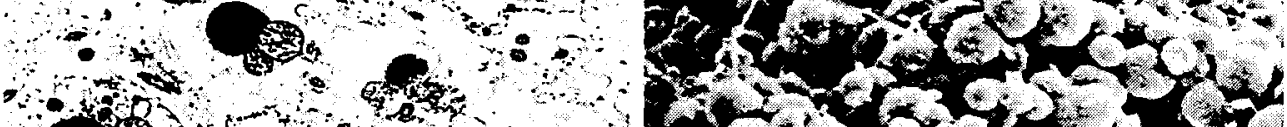
4 a

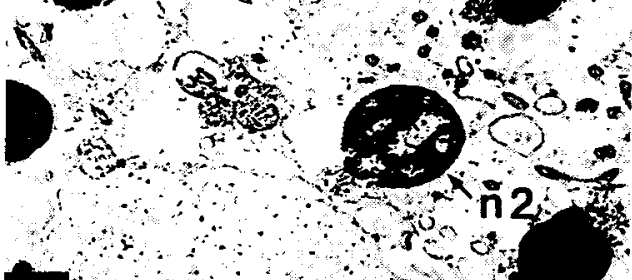

$18 \div \cdots+3$

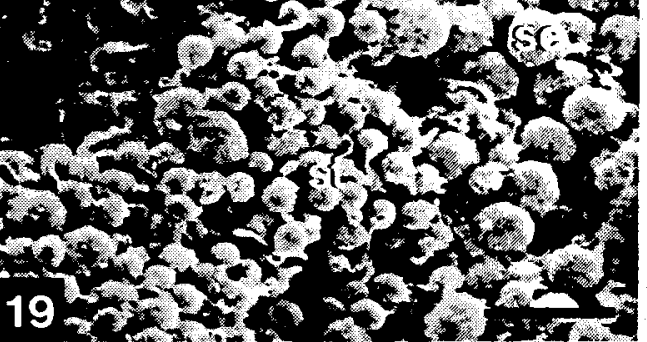


The reproduction of $H$. imbricata has been extensively studied from a number of aspects. Descriptive studies on gametogenesis were carried out by Daly $(1972,1974)$ and Garwood (1981) and this has been coupled with experimental studies on aspects of temperature and photoperiodic control of reproduction in this species (Garwood, 1980; Garwood \& Olive, 1982; Clark, 1988). These have shown that there exists a sophisticated environmental control of reproduction. In contrast to this species there is a paucity of information on the reproductive biology of $H$. impar. It is not unreasonable to suppose, but is by no means certain, that there would be a close similarity in the reproductive biology of the two species. They are morphologically similar and occupy the same habitat niche on temperate rocky shores. In view of the differences in sperm morphology between the two species it would be interesting to examine closely the breeding biology of $H$. impar. It is possible that there are differences in reproductive behavior or fertilisation biology which may account for such different sperm morphology (Franzén, 1977). Differences in certain aspects of reproduction and its endocrine control have been described for other closely related polychaete species such as Nephtys caeca and $N$. hombergi despite the fact that they too are morphologically similar and occupy the same ecological niche (Bentley et al., 1984; Olive et al., 1985).

Acknowledgements. The authors are grateful to the Stiftungsverwaltung der Albert-LudwigsUniversität Freiburg for financial support to KS, and to the Natural Environment Research Council for grant GR3/6841 to MGB. We would also like to thank Dr. A. A. Pacey for criticism of the manuscript and Dr. J. L. S. Cobb and I. Davidson for technical advice.

\section{LITERATURE CITED}

Bentley. M. G. \& Pacey, A. A., 1989. A scanning electron microscopical study of sperm development and activation in Arenicola marina L. (Annelida: Polychaeta). - Invertebr. Reprod. Dev. 15, 211-219.

Bentley, M. G., Olive, P. J. W., Garwood, P. R. \& Wright, N. H., 1984. The spawning and spawning mechanism of Nephtys caeca (Fabricius, 1780) and Nephtys hombergi Savigny, 1818 (Annelida: Polychaeta). - Sarsia 69, 63-68.

Bertout, M., 1976. Spermatogenèse de Nereis diversicolor O. F. Müller (Annélide, Polychète). 1. Evolution du cytoplasme et élaboration de l'acrosome. - J. Microsc. Biol. cellul. 25, 87-94.

Clark, S., 1988. A two phase photoperiodic response controlling the annual gametogenic cycle in Harmothoe imbricata (L.) (Polychaeta: Polynoidae). - Invertebr. Reprod. Dev. 14, 245-266.

Daly, J. M. 1972. The maturation and breeding biology of Harmothoe imbricata (Polychaeta: Polynoidae). - Mar. Biol. 12, 53-66.

Daly, J. M., 1974. Gametogenesis in Harmothoe imbricata (Polychaeta: Polynoidae). - Mar. Biol. 25, 35-40.

Eckelbarger, K. J. \& Grassle, J., 1987. Spermatogenesis, sperm storage and comparative morphology in nine species of Capitella, Capitomastus and Capitellides (Polychaeta: Capitellidae). - Mar. Biol. 95, 415-429.

Fig. 17. Fully differentiated spermatozoa of Harmothoe impar. The heads are ovoid shaped showing pronounced acrosomes and spherical mitochondria. Scale bar $=2 \mu \mathrm{m}$ (f $=$ flagellum, $\mathrm{h}=\mathrm{sperm}$ head, $\mathrm{a}=$ acrosome, $\mathrm{m}=$ mitochondria)

Fig. 18. Transverse section through the testis of Harmothoe impar showing different cell stages, spermatozoa and earlier stages. Scale bar $=2 \mu \mathrm{m}(\mathrm{sz}=$ spermatozoa, $\mathrm{n} 1$ and $\mathrm{n} 2=$ nuclei of earlier stages demonstrating reduction in cell size and nuclear condensation)

Fig. 19. Testis of Harmothoe impar consisting of spermatocytes, spermatids and spermatozoa. Scale bar $=10 \mu \mathrm{m}(\mathrm{sc}=$ spermatocytes, $\mathbf{s t}=$ spermatids, $\mathbf{s z}=$ spermatozoa $)$ 
M. G. Bentley \& K. Serries

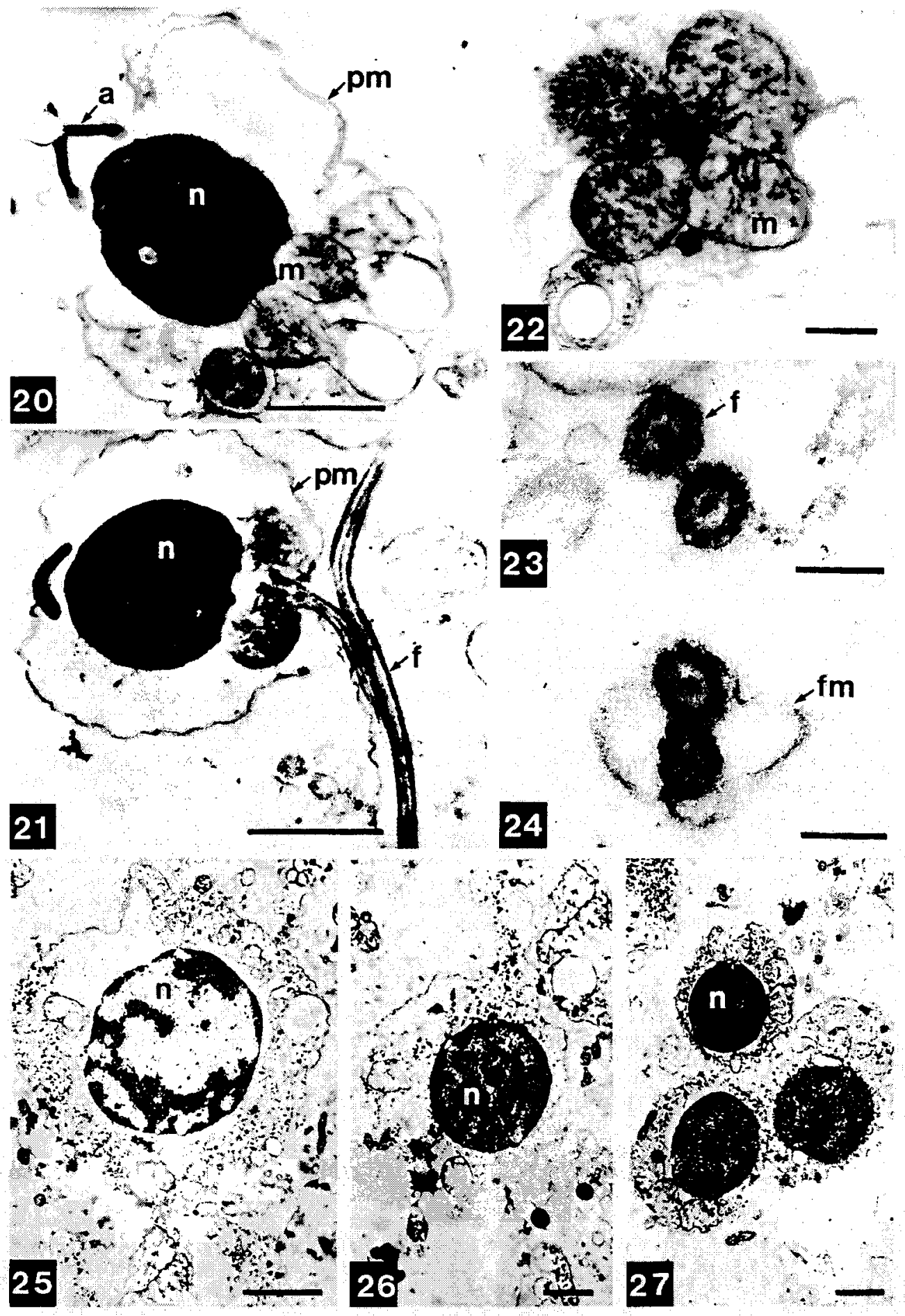


Franzén, $\AA$., 1956. On spermiogenesis, morphology of the spermatozoon, and biology of fertilization among invertebrates. - Zool. Bidr. Upps. 31, 355-482.

Franzén, $\AA$., 1975 . Sperm ultrastructure in some Polychaeta. In: The functional anatomy of the spermatozoon. Ed. by B. A. Afzelius. Pergamon Press, New York, 267-278.

Franzén, $\AA$., 1977. Sperm structure with regard to fertilization biology and phylogenetics. - Verh. dt. zool. Ges. 1977, 123-138.

Franzén, A.., 1987. Spermatogenesis. In: Reproduction of marine invertebrates. Ed. by A. C. Giese, J. S. Pearse \& V. B. Pearse. Blackwell, Palo Alto, Ca. 9, 1-47.

Garwood, P. R., 1980. The role of temperature and daylength in the control of the reproductive cycle of Harmothoe imbricata (L.) (Polychaeta: Polynoidae). - J. exp. mar. Biol. Ecol. 47, 35-53.

Garwood, P. R., 1981. Observations on the cytology of developing female germ cell in the polychaete Harmothoe imbricata (L.). - Int. J. Invertebr. Reprod. Dev. 3, 333-346.

Garwood, P. R. \& Olive, P. J. W., 1982. The influence of photoperiod on oocyte growth and its role in the control of the reproductive cycle of the polychaete Harmothoe imbricata (L.). - Int. J. Invertebr. Reprod. Dev. 5, 161-165.

Lücht, L. \& Pfannenstiel, H. D., 1989. Spermatogenesis in Platynereis massiliensis (Polychaeta: Nereidae). - Helgoländer Meeresunters. 43, 19-28.

Olive, P. J. W., 1983. Annelida-Polychaeta. In: Reproductive biology of invertebrates. Ed. by K. G. Adiyodi \& R. G. Adiyodi. Wiley, London, 2, 321-342.

Olive, P. J. W., Bentley, M. G., Wright, N. H. \& Morgan, P. J., 1985. Reproductive energetics, endocrinology and population dynamics of Nephtys caeca and N. hombergi. - Mar. Biol. 88, 235-246.

Pfannenstiel, H.-D. \& Grünig, Ch., 1990. Spermatogenesis and sperm ultrastructure in the polychaete genus Ophryotrocha (Dorvilleidae). - Helgoländer Meeresunters. 44, 159-171.

Pfannenstiel, H.-D., Lücht, J. \& Grünig, Ch., 1987. Gametogenesis and reproduction in nereid sibling species (Platynereis dumerilii and P. massiliensis). - Bull. biol. Soc. Wash. 7, 272-279.

Rice, S. A., 1981. Spermatogenesis and sperm ultrastructure in three species of Polydora and in Streblospio benedicti (Polychaeta: Spionidae). - Zoomorphology 97, 1-16.

Sawada, N., 1975. Electron microscope studies on sperm differentiation in marine annelid worms. II. Sperm formation in Arenicola brasiliensis. - Dev. Growth Differ. 17, 89-99.

Sawada, N., 1984. Electron microscopical studies of spermatogenesis in polychaetes, - Fortschr. Zool. 29, 100-114.

Westheide, W., 1984. The concept of reproduction in polychaetes with small body size: adaptation in interstitial species. - Fortschr. Zool. 29, 265-287.

Fig. 20. Longitudinal section through a mature sperm of Harmothoe impar showing the acrosome, the oval nucleus and the spherical mitochondria. Expanded plasma membranes surround the sperm cell. Scale bar $=1 \mu \mathrm{m}(\mathrm{a}=$ acrosome, $\mathrm{n}=$ nucleus, $\mathrm{m}=$ mitochondria, $\mathrm{pm}=$ plasma membrane $)$

Fig. 21. Longitudinal section through a mature sperm of Harmothoe impar showing nucleus, flagellum and the plasma membrane. Scale bar $=1 \mu \mathrm{m}(\mathrm{n}=$ nucleus, $\mathrm{f}=$ flagellum, $\mathrm{pm}=$ plasma membrane)

Fig. 22. Transverse section of the middle piece region of Harmothoe impar with four spherical mitochondria surrounding the centriolar complex. Scale bar $=0.5 \mu \mathrm{m}(\mathrm{m}=$ mitochondria)

Fig. 23. Transverse section through two sperm flagella of Harmothoe impar showing the $9+2$ structure of the microtubules. Scale bar $=3 \mu \mathrm{m}(\mathrm{f}=$ flagellum $)$

Fig. 24. Transverse section through two sperm flagella of Harmothoe impar surrounded by a single membrane. Scale bar $=3 \mu \mathrm{m}$ (fm $=$ flagellar membrane)

Fig. 25. Transverse section through a spermatocyte of Harmothoe impar. The nucleus has a heterogenous appearance with most of the electron dense material located around the periphery. Scale bar $=2 \mu \mathrm{m}$ ( $\mathrm{n}=$ nucleus $)$

Fig. 26. Transverse section through a later spermatocyte of Harmothoe impar. The nucleus has a slightly heterogenous appearance. Scale bär $=1 \mu \mathrm{m}$ ( $\mathrm{n}=$ nucleus)

Fig. 27. Transverse section through several spermatids of Harmothoe impar showing increasing homogeneity of the nucleus with a reduction of nuclear diameter associated with chromatin condensation. Scale bar $=1 \mu \mathrm{m}(\mathrm{n}=$ nucleus $)$ 